The comparative inefficiency of government in democratic countries is due in a large measure to the circumstance that a single method, that of the ballotbox, is employed to achieve two wholly different aims-the ascertainment of the popular will, and its execution.

So long as the task of government was little more than to build the postroads, impound stray cattle, punish a few criminals and misdemeanants, and collect a few taxes, it was easy to discern the popular will; and to execute it required little more than common sense.

Today, however, there is practically nothing which is not the concern of government; and in relation to the vast majority of administrative problems the public is not only absolutely incompetent to form an opinion, but is almost equally incompetent to select someone who is competent to form one. Assuming, however, that there. is an in- formed majority opinion in regard to any question of domestic policy; and assuming further-what is a very wild assumption-that this opinion upon this question is reflected at the polls; we still have to face the fact that the carrying out of the public will today is for the most part a matter of extremely technical knowledge; a matter of chemistry, of engineering, of bacteriology, of electricity, of preventive medicine, and of other highly specialized sciences.

It is this shift in the center of gravity of government, which has escaped the notice of those who approach the question of politics' as though patriotism and-democracy were still chiefly concerned in emancipating the people from the tyranny of a king, and who seem to believe that the people will always be content to accept an impotent political freedom as a substitute for effcient administration.

\title{
A BUD VARIATION OF THE LE GRANDE MANITOU DAHLIA
}

\author{
A. D. Shamel
}

$I^{N}$ N THE Journal of Heredity for December, 1918, the writer described a striking bud variation in a dahlia plant found in a garden at Riverside, Cal. Since that time he has been on the lookout for similar instances of dahlia bud sports. In September the dahlias of southern California are in full bloom. While visiting a citrus ranch at Alta Loma on September 9,1919 , my.attention was called by the manager, Mr. W. M. Mertz, to a very interesting case of bud variation in the well-known dahlia variety Le Grande Manitou. The two plants of this variety are growing in the dooryard of the manager's house and are in fine physical condition. The typical flowers have a white ground and are striped and speckled with violet. The flower on the left in Fig. 10 is a representative bloom of the lee Grande Manitou from these plants.

The two Le.Grande Manitou plants both produce, in addition to the typical flowers, blooms having solid violet - color as shown in the flower on the right in Fig. 10. At the time of our examination of these plants one violet bloom was found on each plant to about twelve of the typical flowers of the variety. Mr. Mertz told the writer that up to this time each plant had produced several violet blooms.

As can be seen in the illustration, the two flowers, borne by the same plant, vary in other characteristics than that of color:" The number, shape, arrangement and size of petals are decidedly -different in the two blooms. 

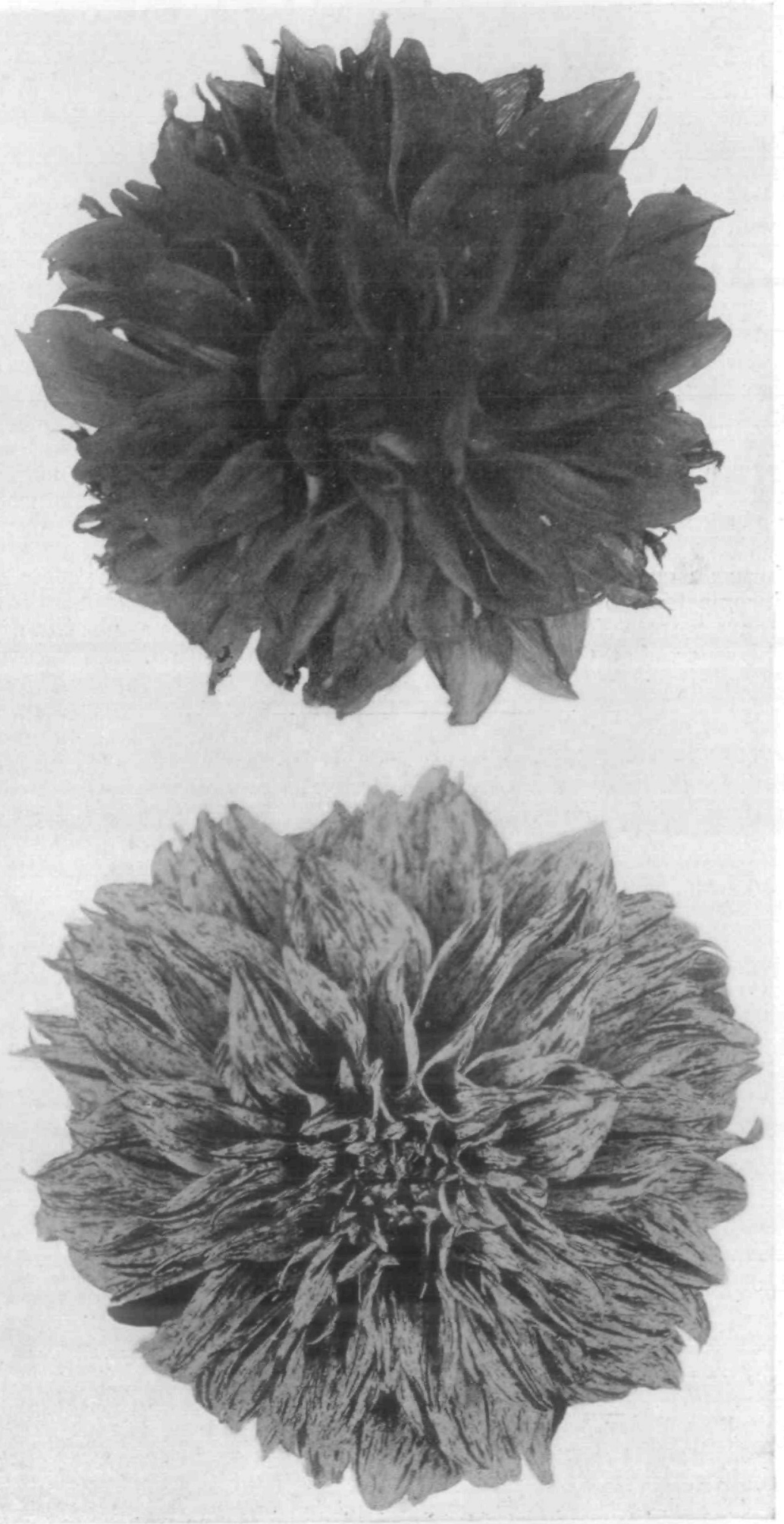

$\pm$

है

으응

至

宅

동

空

牙

올

E

온

。

究

需

声客

․․․

○

?

돈

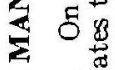

番芯葛

娄言

( 5 듀

다 $E \stackrel{\infty}{*}$

」

造焉

ธ.

品

还

春㨁

莹㝵

昰萑

을

要

$0 \infty$

里

范

.

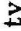

吾 